\title{
The Impact of Human Resource Management Practices on Impersonal Organizational Trust \\ (With special reference to Financial institutions in Sri Lanka)
}

\author{
Nishanthi H.M. ${ }^{1}$, Kulathunga M.G.M.D. ${ }^{2}$ \\ Department of Human Resource Management, \\ Faculty of Commerce and Management Studies, University of Kelaniya, Sri Lanka \\ ${ }^{1}$ menaka@kln.ac.lk, ${ }^{2}$ deepanjalikulathunga@gmail.com
}

\begin{abstract}
The main purpose of this study was to identify whether there is a significant impact of identified strategic human resource management practices (learning and development, communications, performance evaluations and rewards, career opportunities, participation, job design) on impersonal organizational trust with the backing of Social Exchange Theory. This was a cross sectional field study of quantitative nature. Primary data were collected using a well-structured questionnaire. Sample consisted of 100 executive and above employees in the financial institutions in Western Province of Sri Lanka. Descriptive statistics, Pearson correlations and regression analysis were used to analyze data and make conclusions. Findings of the study revealed that there is a significant positive impact of HRM practices on impersonal organizational trust. It revealed that employee trust on the functioning of the entire organization depends on the perceptions of fairness and well-execution of the HRM practices.
\end{abstract} Keywords: Strategic Human Resource Management Practices, Impersonal Organizational Trust.

\section{Introduction}

Organizations operating in the same industry often pay severe attention on how to gain competitive advantage over existing firms and new entrants. Financial institutions in Sri Lanka also operate in very competitive environments locally and globally. This results in greater competition among the firms to secure a competitive edge over others (Musgrave, 2011) Basically three types of resources provide competitive advantage, namely physical capital resources, organizational capital resources and human capital resources. Of these, human resources tend to be the most important asset which creates an edge through knowledge creation (Barney, 2001).

${ }^{1}$ https://orcid.org/0000-0001-8519-1501

Kelaniya Journal of Management | 2018 | Vol. 07 | Issue 01 | Page 68 
Further, impersonal trust is specifically important in a knowledge based organization because it is known to support knowledge creation processes and related interactions. (Tyler, 2003). It is said that efficiency of competitive advantage in an organization is possible only when interdependent actors work together effectively in a climate of positive impersonal trust. (Zeffane \& Connell, 2003). How, then, can organization built and retain impersonal trust within the organization? One way is to use Human Resource Management (HRM) practices to build a positive climate of impersonal trust. Employees are not committed to the organization if they mistrust or if there is gap in trusting the organisation. Hence, trust is of critical importance, because without the commitment and support of employees, managers are likely to experience lower productivity and poor organizational performance in organizations today. According to Vanhala, Puumalainen and Blomqvist (2011, pp. 492), "Organization can enhance trustworthiness in the eyes of employees by creating structures and processes that make trusting successful. Impersonal organizational trust means an individual employee's expectation with regard to the employer organization's capability and fairness."

Organizations use various types of HRM practices in order to enhance the skills of their employees, focusing their efforts on improving the quality of current workforce through training and development, for example. The employee should be motivated to perform their jobs effectively and may be affected by merit awards or incentive compensation system. Employees should also have the opportunity to participate in the decision making. They should also have the opportunity to express their views. Furthermore, organizations that take the views of their employees in to consideration will find a positive impact on employee perceptions of fairness and behavioral output (Way, 2002). These would result in enhancing the trustworthiness of the organisation in the eyes of the employees. In this study, HRM practices refer to the strategic practices that could have an impact on the impersonal organizational trust. Delery and Doty (1996) defined strategic HRM practices as "those that are theoretically or empirically related to overall organizational performance", and identified eighteen HRM practices covering six main areas of HRM: Learning and development, Communication, performance evaluation and rewards, career opportunity, participation and job design (p.805)." As stated before, Barney and Wright (1998) also argue that the most corporate annual reports boldly state that the organization's people are the most important assets to the organization. But in today's organizations are endeavoring to secure the competitive edge over its competitors through reducing cost, improved quality of service and product and being more innovative. However, organizations are highly focused on profit oriented targets than the 
people oriented targets. When organizations are required to cut costs, they look first to reduce investments in people in the form of training, wages and headcounts, etc. The inevitable outcome of such downsizing and cost cutting is mistrust and a trust gap between managers and employees and in the whole organization (Tyler, 2003). Employees are not committed to the organization within this climate of mistrust. This is of critical importance, because without the commitment and support of employees, managers are likely to experience lower productivity and poor organizational performance in organizations today. Hence, assessing employee impersonal trust on organisation is of greater value. Although there have been many studies that link numerous human resource management practices with trust (e.g. McCauley \& Kuhnert, 1992; Whitener, 1998; Gillespie \& Mann, 2004; Zeffane \& Connell, 2003; Mishra \& Morrissey, 1990), it has only been looked at in an interactional level between employees and managers. Researchers who have looked at organizational trust has only looked at with trust in senior management (McCauley \& Kuhnert, 1992; Costigan, Iiter, \& Berman, 1998; Mayer \& Davis, 1999). Only Vanhala and Ahteela (2011) have looked at it in an organisational perspective by taking its major dimensions into consideration. Hence, studies conducted taking impersonal trust and HRM practices are very few. Consequently, there has been an increase in research focusing on the organisational level impact of HRM practices in the past ten years in Sri Lankan context (Serasinghe \& Opatha, 2007). But so far none have undertaken a comprehensive study of impact of HRM practices on trust in Sri Lankan context. Further, within the same context, a study which assesses impact of HRM practices on impersonal organizational trust with relation to financial institutions has also not also been conducted to the best of knowledge of the researchers. Hence, the current study contributes to fill this theoretical and empirical research gaps. Authors have already identified that there is lack of impersonal trust within the financial institutions through the informal discussion had with the employees. So the main objective of this study is to find out the effects of various HRM practices on the impersonal organizational trust in financial institutions in Sri Lanka.

HRM practices are usually practiced in all organisations and this study will help to identify what are highly affected factors for impersonal organizational trust and what are the key HRM practices to build a positive cycle of impersonal trust within the financial institutions to achieve the competitive advantage through trustworthy work environments. As well as, an organization could offer a practical solution to the problem of building and retaining trust by developing a current system or specific methods. 


\section{Literature review and Hypothesis Development}

Organizations from diverse business settings increasingly recognize the potential of their personnel as a source of competitive advantage. The creation of competitive advantage through employees requires close attention to the personal related practices that best leverage these assets. Consequently, there has been an increase in research focusing on the organizationallevel impact of HRM practices in the past years (Delaney \& Huselid, 1996; Wright, Gardner, \& Moynihan, 2003). According to Sheppeck and Militello (2000), HRM issues are often determined in terms of how organizations deal with their human resources, and the emphasis has been on operationally oriented tools and procedures. According to Tzafrir (2005), building and retaining organizational trust must involve HRM practices in that they represent the relationships, interaction and communication between the organization and its employees, as well as its whole philosophy.

The dependent variable impersonal organizational trust has been described by Vanhala and Ahteela (2011) as individual employee opinion/perception of the employing organisation, which consists of two dimensions as capability and fairness. According to Vanhala and Ahteela (2011), capability dimension consists of five components as organizing the operational activities, sustainability of the organization, management of the business and people, technological reliability and competitiveness whereas fairness element consists of education and career development, equitable pay and effective communication by way of having free access to needed information.

When analyzing the relationship between HRM practices and organizational trust, Tzafrir (2005) states that, when building and retaining organizational trust must use HRM practices in that they represent the relationships, interaction and communication between the organization and its employees, as well as its whole philosophy. In the current study, HRM practices have been identified as the strategic HRM practices that impacts the impersonal dimension of organizational trust such as participation, job design, etc. (Vanhala \& Ahteela, 2011). Social exchange theory can be used to explain this relationship in detail (Cropanzano \& Mitchell, 2005). This highlights the interchange/exchange that happens between organizational trust and HRM practices. Greater the care, support provided by the organisation by executing HRM practices effectively, greater would be the trust of employees on the organisation. Whitener (1998) states that there it is the notion that proper implementation of HRM practices would result in enhanced organizational trust and not the other way around. This is because the HRM 
practices are emphasizing on the relationships, interactions and communications that happen within the organisations which would ultimately result in creating trustworthiness towards the employing organisation. However, Vanhala and Ahteela (2011) argue that this relationship can be reciprocal as trusting the organisation might result in generating benefits to its employees through effective implementation of HRM practices.

According to McCauley and Kuhnert (1992), trust between employees and management is not interpersonal in nature, but derives from the roles, rules, and structured relations of the organization. They further argue that trust is determined by the fairness and efficiency of the organizational structures. Vanhala and Ritala (2016) argue that impersonal trust as an individual employee's attitude based on his or her perception and evaluation of the employer organization, which thus operate on the individual level. HRM practices influence the entire organization, and it has been said that one of the emerging challenge is to build a positive cycle of trust within it (Tzafrir, Baruch \& Dolan, 2004). Gould-Williams (2003) found that HRM practices had a positive effect on both interpersonal and impersonal trust. Based on these arguments following hypothesis is formed.

$\mathrm{H}_{1}$ : There is an impact of HRM practices on impersonal organizational trust.

In the current study, several HRM practices are examined which were considered to be having a greater strategic importance to the organisations: learning and development, communication, performance evaluation and rewards, career opportunities, participation and job design. Hence, following sub hypotheses are formulated to discuss their impact on the impersonal organizational trust.

Training activities and employee advancement opportunities have been found to have a positive impact on organizational trust (Whitener, 1998). According to Tzafrir et al. (2004), giving employees more opportunities for advancement and learning, results in greater trust created about the organisations in employees. Employees get an assurance about the organisation as they feel that organisation is investing on them in order to retain them. Hence, providing training opportunities would result in trusting the organisation and their managers. Accordingly, following hypothesis is formed.

$\mathrm{H}_{1 \mathrm{a}}$ : There is an impact of learning and development on impersonal organizational trust According to Pfeffer and Veiga (1999), communication is essential in order to generate a hightrust organisation. Tzafrir et al. (2004), also stresses that opportunity for open and direct communicate fosters a culture of trust within the organisation. If employees have the assurance 
that their ideas, issues would be cared and listened to by the organizational superiors, greater would be trust placed on the organisation. Whitener (1997), Shockley-Zalabak, Ellis, and Winograd (2000) also confirms this idea stating employee trust in management and the organisation depends on the extent of open and direct communication availability. Hence, following sub hypothesis is formed to test this relationship.

$\mathrm{H}_{1 \mathrm{~b}}$ : There is an impact of communication on impersonal organizational trust.

The perceived fairness of an organization's performance appraisal system is related to high level trust (McCauley \& Kuhnert, 1992). According to the study conducted by Mayer and Davis (1999), trust in top management has increased drastically with the implementation of new performance appraisal system which is clear and correct in assessing employee performance than the old system. Pearce, Branyiczki and Bigley (2000) also found that if the performance evaluation system is implemented giving procedural justice, much trust is created towards the organisation. Hence, following sub hypothesis is created to test the impact of performance evaluation on impersonal organizational trust.

$\mathrm{H}_{1 \mathrm{c}}$ : There is an impact of performance evaluation on impersonal organizational trust. Provision of career advancement opportunities are essential in order to show that organisations value their people. This creates a strong bond between the employer and the employee (Harel \& Tzafrir, 1999) which creates a climate of trust between those parties. According to Vanhala and Ahteela (2011), fair job rotations, promotional opportunities would pose employees to have greater trust in their organisations. Hence, based on these augments following hypothesis can be devised.

$\mathrm{H}_{1 \mathrm{~d}}$ : There is an impact of career development on impersonal organizational trust.

Mishra (1996) states that if employees get an opportunity to share their ideas, opinions and if those ideas, opinions are taken into consideration when making decisions, employees perceive that they are being considered as part of the organisation. This enhances the mutual trust between the organisation and the employees. Further, as per Dirks and Ferrin (2001) if business decisions are taken jointly being more democratic, not only employees will comply to the decisions taken but also they begin to trust their organisation. Hence, this remove any boundary between managers and employees, enhancing mutual trust between them. Hence, Vanhala and Ahteela (2011) convey that employee participation in decision making creates organizational impersonal trust. Following is the hypothesis to test this phenomenon further in Sri Lankan context. 
$\mathrm{H}_{1 \mathrm{e}}$ : There is an impact of employee participation on impersonal organizational trust.

Trust for an organisation can be increased inevitably if the organizational structure itself be is adaptive to the needs of the employees (Shockley-Zalabak et al., 2000). Further, jobs designed should be free of task and role conflicts. If the organisation promotes clear job design through carefully crafted job descriptions and analyses, result is the greater trust placed on the employing organisation. Hence, it could be argued that job design creates high levels of impersonal organizational trust (Vanhala \& Ahteela, 2011). In an environment in which work classification is clearly defied, employees will be willing to accept policies and decisions if they are based on fair process and they are given adequate information (Tzafrir et al., 2004). Hence, following is the hypothesis to examine this point of view.

$\mathrm{H}_{1 \mathrm{f}}$ : There is an impact of job design on impersonal organizational trust.

\section{Conceptual Framework}

This study tests HRM practices as the independent variables and impersonal organizational trust as the dependent. According to Cropanzano and Mitchell (2005) trust is an outcome of favorable social exchange: when employees see others acting in ways that imply that others trust them, employees are more disposed to reciprocate by trusting in others more.



Figure 1 Conceptual Framework of the Study

Source: Vanhala \& Ahteela (2011) 


\section{Methods}

This study is of explanatory nature as it attempts to investigate a 'why' question to explain impact of the variables in this model. As data for this study are collected only at one point in time, this is regarded as a cross sectional study. The unit of analysis here is the individual financial institutions' employee (executives and above executives). The population of the study is all the executives/above executives of financial institutions in Sri Lanka. The sample size of the study is 100 executive and above employees. The researchers employed convenience sampling technique and the data collection was done through a self-administered anonymous standard questionnaire. After the data collection was performed, data were analysed using SPSS version 20. Data was screened before using for hypotheses testing in order to ensure no mistakes were done in data entering. Then the data were tested to ensure normality, linearity, homoscedasticity, validity, reliability, correlation as well as common method bias. Multiple regression analysis was used to test the hypotheses.

\section{Measures}

The dependent variable- impersonal organizational trust was measured by administering the scale developed and validated by Vanhala et al (2011). Selected HRM practices which were treated as independent variables were measured using the scale established and validated by Delery and Doty (1996). The questionnaire included twenty-four (24) likert scale questions on a range of five.

\section{Findings and discussion}

\section{Findings}

\section{Sample composition}

The sample consisted of 100 executives and above employees in the financial institutions in Sri Lanka. According to processed data, majority of the respondents (62\%) are male. Majority of the executive and above employees (53\%) belonged to the age category of 30-39 years. From the sample majority of executive and above employees (43\%) were degree holders. Further, most of the respondents $(51 \%)$ were not married and majority of the respondents $(41 \%)$ have been working for the company for 1-3 years. 


\section{Data Reliability}

Inter item consistency reliability for all latent variables was also tested using the Cronbach's Alpha coefficient and the results are shown in Table 01. As overall reliability coefficients for all measures are above 7 Hence, it is deemed to be reliable (Sekaran \& Bougie, 2011).

\section{Table 01: Data Reliability}

\begin{tabular}{|c|c|c|c|}
\hline Constructs & Dimensions & Cronbach's Alpha & No of Items \\
\hline \multirow[t]{7}{*}{ Human Resc } & urce Management Practices & 0.92 & 18 \\
\hline & Learning and Development & 0.75 & 3 \\
\hline & Communication & 0.76 & 3 \\
\hline & Performance Evaluation \& Rewards & 0.82 & 4 \\
\hline & Career Opportunities & 0.73 & 3 \\
\hline & Participation & 0.83 & 2 \\
\hline & Job Design & 0.74 & 3 \\
\hline \multicolumn{2}{|c|}{ Impersonal Organizational Trust } & 0.86 & 17 \\
\hline & Capability & 0.84 & 11 \\
\hline & Fairness & 0.73 & 6 \\
\hline
\end{tabular}

Source: Survey data

\section{Correlation Analysis}

To examine the relationships between independent variables and the dependent variable, impersonal organizational trust, scatter plots were constructed. According to scatter plots the relationships were linear between learning and development, communication, performance evaluation and rewards, career opportunities, participation and job design with the impersonal organizational trust. As the relationships were linear the Pearson correlation coefficient was applied to test the strength of association between the HRM practice and organizational impersonal trust. All relationships were significant at 0.01 level showing moderate to high associations between HRM practices and impersonal organizational trust. The statistical results revealed that there is a positive relationship between identified HRM practices and impersonal 
organizational trust of executive and above executive level employee working in the financial institution.

Table 02: Correlations among HRM practices and Impersonal organizational trust

\begin{tabular}{|c|c|c|c|c|c|c|c|}
\hline Construct & $\mathbf{L D}$ & $\mathbf{C}$ & PE & $\mathrm{CO}$ & $\mathbf{P}$ & JD & IMT \\
\hline LD & 1 & & & & & & \\
\hline $\mathrm{C}$ & $0.461^{* *}$ & & & & & & \\
\hline PE & $0.477^{* *}$ & $0.573^{* *}$ & & & & & \\
\hline $\mathrm{CO}$ & $0.428^{* *}$ & $0.281^{* *}$ & $0.394^{* *}$ & & & & \\
\hline $\mathrm{P}$ & $0.525^{* *}$ & $0.425^{* *}$ & $0.440^{* *}$ & $0.539^{* *}$ & & & \\
\hline JD & $0.501^{* *}$ & $0.396^{* *}$ & $0.470^{* *}$ & $0.567^{* *}$ & $0.458^{* *}$ & & \\
\hline IMT & $0.857^{* *}$ & $0.645^{\text {** }}$ & $0.660^{\text {** }}$ & $0.767^{* *}$ & $0.805^{\text {** }}$ & $0.846^{* *}$ & 1 \\
\hline
\end{tabular}

**. Correlation is significant at the 0.01 level (2-tailed).

Note (01): LD- Learning and development, C-Communication, PE- Performance Evaluation and Reward, P- Participation, JD- Job design, IMT- Impersonal organizational Trust.

Note (02): (1) Between .1-.3: small effect. (2) Between .3-.5: medium effect. (3) Above .5: large effect.

\section{Hypotheses Testing}

According to Table 03, multiple regression analysis indicates that there is positive significant impact of HRM practices on impersonal organizational trust. The adjusted $\mathrm{R}^{2}$ is 0.935 at a significance level of .01. This explains that for $93.5 \%$ of impact on the trust on the organisation is based on the execution of HR practices (learning and development, communication, performance evaluation \& rewards, career opportunities, participation, job design). Further, the standardized beta values for each of the independent variables are positive $(.162, .230, .120$, $.264, .243, .206$.). Hence, it could also be noted that there are positive associations between the selected HR practices and the impersonal organizational trust. Hence, based on these data hypotheses of the study $\left(\mathrm{H}_{1 \mathrm{a}}, \mathrm{H}_{1 \mathrm{~b}}, \mathrm{H}_{1 \mathrm{c}}, \mathrm{H}_{1 \mathrm{~d}}, \mathrm{H}_{1 \mathrm{e}}, \mathrm{H}_{1 \mathrm{f}}\right.$ are accepted. 
Table 03: Multiple regression analysis to test the impact of HRM Practices on Impersonal organizational trust

\begin{tabular}{lccc}
\hline \multicolumn{1}{c}{ Variables } & $\boldsymbol{\beta}$ & $\mathbf{t}$ & Sig. \\
\hline Predictors & .162 & 8.935 & .000 \\
Learning and Development & .230 & 2.822 & .006 \\
Communication & .120 & 6.455 & .000 \\
Performance Evaluation \& Rewards & .264 & 3.285 & .001 \\
Career Opportunities & .243 & 6.573 & .000 \\
Participation & .206 & 5.320 & .000 \\
Job Design & & & \\
& & .939 & \\
$\mathrm{R}^{2}$ & & .935 & \\
Adjusted $R^{2}$ & & 238.827 & \\
$\Delta \mathrm{F}$ & & .000 & \\
Sig. $\Delta \mathrm{F}$ & & & \\
\hline
\end{tabular}

Source: Survey Data

\section{Discussion of Key Findings}

The current study was focused towards the identification of the impact of HRM practices on impersonal organizational trust of executive and above executive employees in financial institutions in Sri Lanka. One sub objective of the study was to identify the level of HRM practices in financial institutions in Sri Lanka. Same time it was aimed to study the level of impersonal trust of the financial institution's employees. The standard questionnaire consisted of 35 questions, which was measured using the five point likert scale which exceeded the minimum reliability recommended level of $0.07 \mathrm{used}$ as the data gathering techniques. The response rate was $90.83 \%$. Results were averaged and analyzed using descriptive statistics, correlation and regression to extract the impact and the relationship of the HRM practices and impersonal organizational trust. The results revealed a mean value of 3.4 out of 5 on all HRM practices. Hence, it was noted that satisfaction level on the execution of HRM practices were in moderate level in the financial institutions. Communication, career opportunity and performance evaluations were highest rated practices in financial institutions. With a mean of 3.5 out of 5 , reveals a moderate level of impersonal trust on organisations. 
Based on findings, correlation between learning and development and impersonal organizational trust was .857 . Other relationships in communications, performance evaluation, career opportunity, participation and job design with impersonal organizational trust shown Pearson correlations of $.645, .660, .767, .805$ and .846 respectively with a confidence level of 99\%. This indicated strong positive relationships between the variables. The research findings have indicated that impersonal trust of employees tend to become strong due to the proper execution of HRM practices.

Findings also revealed that impact of HRM practices towards the impersonal organizational trust is at $93.5 \%$. Therefore, it implicated that impact of the other factors towards the impersonal organizational trust was just amounting to $6.5 \%$. Present study accepted the hypothesis $1\left(\mathrm{H}_{1}\right)$ concluding that HRM practices appear to play an important role in the development of employee trust in the employer organization in positive manner. Similarly, HRM practices influence the entire organization, and it has been said that one of the emerging challenges is to build a positive phase of trust within it (Tzafrir et al, 2004). Moreover, GouldWilliams (2003) found that HRM practices had a positive effect on both interpersonal and impersonal trust.

Further, adjusted $\mathrm{R}^{2}$ revealed that real impact of learning and development towards the impersonal organizational trust was $73.1 \%$ and then impact of other factors contributed towards impersonal organization trust was $6.9 \%$. Findings stress the importance to organizations to invest in learning and development possibilities of their employees. It seems that based on employee's perceptions of their employer organizations potential and the extent to which they benefit from learning and development opportunities is associated with impersonal trust.

Findings further elaborate a positive impact of communication on impersonal organizational trust. Communication will positively influence by $41 \%$ on the Impersonal organizational trust in financial institution and also this is statistically significant in $99 \%$ confidence level. This concluded that communication has a positive and significant influence on employees' impersonal trust in their organizations. Similarly, Tzafrir (2004) stated that if the level of organizational communication is high, it leads to an open and confident atmosphere, which in turn generates trust. According to the results, impact of performance evaluation towards the impersonal organizational trust at $43 \%$. Therefore, it implicated that impact of the other factors towards the impersonal organizational trust was 57\%. Therefore, researchers found that uniformly applied performance evaluation and reward system that is fair and objective had a positive impact on employees' impersonal trust in the organization. Similar findings were 
visible through the studies conducted by Mccauley (1992) and Zeffane and Connell (2003). Their studies found out that internal career opportunities are also positively related to employees' trust in the employer organization. Outcomes further confirmed that there is positive impact of employee participation on impersonal organizational trust going in line with the findings by Mishra (1996).

In sum, the results of this study provide strong empirical support for the tested hypotheses. Learning and development explained most of the variation in impersonal trust $(73.1 \%)$ and communication the least (41\%). Major finding of this study is that HRM practices do influence impersonal trust. Researchers argue that employee trust in the whole organization is connected to their perceptions of the fairness and functioning of HRM practices, which could then be used in order to build up this impersonal organizational trust.

This study contributes to the growing amount of literature on the role of trust in the context of organizational relationships. Although it is recognized that trust in organizations operates at multiple levels (Vanhala \& Ahteela, 2011), scholars have used the concept of impersonal trust (e.g. trust between employees and managers or top management) in attesting the importance of HRM practices in building trust towards the organisation. The previous study on impersonal organizational trust by Vanhala and Ahteela (2011) had addressed the interpersonal trust in European context. As it was the first study which was focusing on impersonal element of organizational trust it ads greater value to investigate its validity in the Sri Lankan context. Hence, researchers have further confirmed their findings in the Asian context and adds to the literature in considering the HRM-trust link in terms of impersonal organizational trust.

As per managerial implications, organisations should provide greater support to implement Human Resource Management practices, in order to create high levels of impersonal organizational trust which intern contributions to high retention rates in employees. In long term, this is beneficial to organisations as this reduces costs involve in labour attrition, low morale and motivation.

\section{Limitations and Suggestions for Further Research}

Current study focused on identifying effects of several HRM practices on impersonal organizational trust in Financial institutions in Sri Lanka. However, current study only focused on six strategic HRM practices whereas there might be other HRM practices which might contribute to creating better organizational trust. Hence, future studies should include and test those practices as well. Sample size was limited to 100 executives and above employees, 
whereas island wide sample should have selected for better representation of the population. Researchers used only the questionnaire method in data collection. But, data triangulation through interviews and focus group discussions would have given a complete understanding on the factors which really enhance impersonal organizational trust. Further, in future to have a better view on impersonal organizational trust and the impact of HRM practices cross industry analysis can be suggested.

\section{Conclusion}

This study highlights the importance of impersonal organizational trust and opens up trust with new opportunities in terms of enhancing understanding of the phenomenon of HRM practices in financial institutions in Sri Lanka. Creation of impersonal trust seems to be critical in the context of financial institutions. Thus, managers should direct their efforts at increasing awareness of how to build a positive, cycle of trust using HRM practices, and of its consequences. The new knowledge and findings in this study is provided, will help to make people in managerial positions as well as those engaged in HR development and change management to become more aware of organizational trust and its implications. More specifically, on the practical level the results could be used to measure impersonal trust in an organizational context, to strength of trust in employee-employer relationships, and to enhance understanding of the role of trust in the relationship between HRM practices and organizational success.

\section{References}

Barney, J. B. (2001). Is the resource-based "view" a useful perspective for strategic management research? Yes. Academy of management review, 26(1), 41-56.

Barney, J. B., \& Wright, P. M. (1998). On becoming a strategic partner: The role of human resources in gaining competitive advantage. Human Resource Management: Published in Cooperation with the School of Business Administration, The University of Michigan and in alliance with the Society of Human Resources Management, 37(1), 31-46.https://doi.org/10.1002/(SICI)1099-050X(199821)37:1<31::AID-

\section{HRM4>3.0.CO;2-W}

Costigan, R. D., Iiter, S. S., \& Berman, J. J. (1998). A multi-dimensional study of trust in organizations. Journal of managerial issues, 303-317. 
Cropanzano, R., \& Mitchell, M. S. (2005). Social exchange theory: An interdisciplinary review. Journal of management, 31(6), 874-900. https://doi.org/10.1177/0149206305279602

Delaney, J. T., \& Huselid, M. A. (1996). The impact of human resource management practices on perceptions of organizational performance. Academy of Management journal, 39(4), 949-969.

Delery, J. E., \& Doty, D. H. (1996). Modes of theorizing in strategic human resource management: Tests of universalistic, contingency, and configurational performance predictions. Academy of management Journal, 39(4), 802-835. https://doi.org/10.5465/256713

Dirks, K. T., \& Ferrin, D. L. (2001). The role of trust in organizational settings. Organization science, 12(4), 450-467. https://doi.org/10.1287/orsc.12.4.450.10640

Gillespie, N. A., \& Mann, L. (2004). Transformational leadership and shared values: The building blocks of trust. Journal of Managerial Psychology, 19(6), 588-607. https://doi.org/10.1108/02683940410551507

Gould-Williams, J. (2003). The importance of HR practices and workplace trust in achieving superior performance: a study of public-sector organizations. International journal of human resource management, $14(1), \quad 28-54$. https://doi.org/10.1080/09585190210158501

Harel, G. H., \& Tzafrir, S. S. (1999). The effect of human resource management practices on the perceptions of organizational and market performance of the firm. Human Resource Management: Published in Cooperation with the School of Business Administration, The University of Michigan and in alliance with the Society of Human Resources Management, $\quad 38(3), \quad$ 185-199. $\quad$ https://doi.org/10.1002/(SICI)1099$\underline{050 X(199923) 38: 3<185:: A I D-H R M 2>3.0 . C O ; 2-Y}$

Mayer, R. C., \& Davis, J. H. (1999). The effect of the performance appraisal system on trust for management: A field quasi-experiment. Journal of applied psychology, 84(1), 123. https://doi.org/10.1037/0021-9010.84.1.123

McCauley, D. P., \& Kuhnert, K. W. (1992). A theoretical review and empirical investigation of employee trust in management. Public Administration Quarterly, 265-284. 
Mishra, J., \& Morrissey, M. A. (1990). Trust in employee/employer relationships: A survey of West Michigan managers. Public Personnel Management, 19(4), 443-486. https://doi.org/10.1177/009102609001900408

Mishra, A.K. (1996), “Organizational responses to crisis: the centrality of trust”, in Kramer, R.M. and Tyler, T.R. (Eds), Trust in Organizations: Frontiers of Theory and Research, Sage, Thousand Oaks, CA, pp. 261-87. https://doi.org/10.4135/9781452243610.n13

Musgrave, J. (2011). Moving towards responsible events management. Worldwide Hospitality and Tourism Themes, 3(3), 258-274 https://doi.org/10.1108/17554211111142211

Opatha, H. H. D. N. P. (2009). Human Resource Management: Personnel. Colombo: Department of HRM, University of Jayewardenepura. https://doi.org/10.31357/bkc.fmsc.00001

Pfeffer, J., \& Veiga, J. F. (1999). Putting people first for organizational success. Academy of Management Perspectives, 13(2), 37-48. https://doi.org/10.5465/ame.1999.1899547

Pearce, J.L., Branyiczki, I. and Bigley, G.A. (2000), "Insufficient bureaucracy: trust and commitment in particularistic organizations", Organization Science, 11(1), 148-62. https://doi.org/10.1287/orsc.11.2.148.12508

Saunders, M. N. (2011). Research methods for business students, 5/e. Pearson Education India.

Serasinghe, D.K.S., \& Opatha, H.H.D.N.P (2007) Human Resource Management Practices in Listed Firms in Sri Lanka. Sri Lankan Journal of Human Resource Management, 1(1), 36 - 52. https://doi.org/10.4038/sljhrm.v1i1.5110

Sheppeck, M. A., \& Militello, J. (2000). Strategic HR configurations and organizational performance. Human Resource Management, 39(1), 5-16. https://doi.org/10.1002/(SICI)1099-050X(200021)39:1<5::AID-HRM2>3.0.CO;2-I

Shockley-Zalabak, P., Ellis, K., \& Winograd, G. (2000). Organizational trust: What it means, why it matters. Organization Development Journal, 18(4), 35.

Tyler, T. R. (2003). Trust within organisations. Personnel review, 32(5), 556-568. https://doi.org/10.1108/00483480310488333

Tzafrir, S. S. (2005). The relationship between trust, HRM practices and firm performance. The International Journal of Human Resource Management, 16(9), 1600-1622. https://doi.org/10.1080/09585190500239135 
Tzafrir, S. S., Baruch, Y., \& Dolan, S. L. (2004). The consequences of emerging HRM practices for employees' trust in their managers. Personnel Review, 33(6), 628-647. https://doi.org/10.1108/00483480410561529

Vanhala, M., \& Ahteela, R. (2011). The effect of HRM practices on impersonal organizational trust. Management Research Review, 34(8), 869-888. https://doi.org/10.1108/01409171111152493

Vanhala, M., Puumalainen, K., \& Blomqvist, K. (2011). Impersonal trust: The development of the construct and the scale. Personnel Review, 40(4), 485-513. https://doi.org/10.1108/00483481111133354

Way, S. A. (2002). High performance work systems and intermediate indicators of firm performance within the US small business sector. Journal of management, 28(6), 765 785. https://doi.org/10.1177/014920630202800604

Whitener, E. M. (1998). The impact of human resource activities on employee trust. Human Resource Management Review, 7(4), 389-404. https://doi.org/10.1016/S1053$\underline{4822(97) 90026-7}$

Wright, P. M., Gardner, T. M., \& Moynihan, L. M. (2003). The impact of HR practices on the performance of business units. Human Resource Management Journal, 13(3), 21-36. https://doi.org/10.1111/j.1748-8583.2003.tb00096.x

Zeffane, R., \& Connell, J. (2003). Trust and HRM in the new millennium. International Journal of Human Resource Management, 14(1), 3-11. https://doi.org/10.1080/09585190210158484 